\title{
Tendencje $w$ orzekaniu o potrzebie nauczania indywidualnego w województwie małopolskim
}

\begin{abstract}
Izabella Gałuszka, Tendencje w orzekaniu o potrzebie nauczania indywidualnego w województwie matopolskim [Tendencies in predication of the need for individual teaching in the Malopolska province]. Interdyscyplinarne Konteksty Pedagogiki Specjalnej, nr 22, Poznań 2018. Pp. 355-374. Adam Mickiewicz University Press. ISSN 2300-391X. DOI: https:// doi.org/10.14746/ikps.2018.22.20

The article is devoted to individual teaching as a form of education for pupils whose health condition prevents or significantly impedes school attendance. It is awarded by public psychological and pedagogical counselors at every educational stage from pre-school to post-gymnasium. Due to the time of research and collected data, the theoretical part of the book can be found not only in the laws and regulations of 2017 , but also in the regulations which are no longer binding. The purpose of the dissertation is to answer the questions: What is individual teaching? On what basis can this form of education be obtained? What are the possible consequences of individual teaching? In the research part, the author analyzes data obtained from the resources of deliberately selected psychological and pedagogical clinics in Małopolskie Voivodship. The analysis was compiled with data from the Statistical Office in Krakow concerning the school year 2014/2015 and discussed.
\end{abstract}

KEY WORDS: education, special educational needs, acts of educational law, teaching at home some groups of pupils with SEN 
Celem edukacji jest umożliwienie każdej jednostce objęcia w posiadanie jej indywidualnego potencjatu

John Dewey

\section{Wstęp}

Rok 2017 był czasem wielu systemowych zmian, dotyczących edukacji dzieci i młodzieży. Indywidualne nauczanie dzieci i młodzieży w roku szkolnym 2017/2018 organizowane jest na podstawie: obowiązującej od 1 września 2017 r. Ustawy z 14 grudnia 2016 r. - Prawo oświatowe ${ }^{1}$, rozporządzenia Ministra Edukacji Narodowej z dnia 28 sierpnia 2017 r. zmieniającego rozporządzenie w sprawie indywidualnego obowiązkowego rocznego przygotowania przedszkolnego dzieci i indywidualnego nauczania dzieci i młodzieży ${ }^{2}$ oraz rozporządzenia Ministra Edukacji Narodowej z dnia 7 września 2017 r. w sprawie orzeczeń i opinii wydawanych przez zespoły orzekające działające $w$ publicznych poradniach psychologicznopedagogicznych ${ }^{3}$. Niezależnie od zmiany przepisów prawa oświatowego, prezentowanych dalej badań ma na celu zwrócić większą uwagę na procedury i częstotliwość orzekania o potrzebie nauczania indywidualnego.

Podstawowym wyznacznikiem edukacji, podkreśla Józefa Bałachowicz ${ }^{4}$, jest realizacja nauczania skupionego na dziecku, prowadzącego do maksymalizacji jego potencjału osobowościowego i rozwoju jego podmiotowości. Taka optymalizacja rozwoju jest możliwa tylko wówczas, gdy zapewnione zostaną odpowiednie warunki edukacji, oparte na zasadzie indywidualizacji kształcenia. Indywidualizacja ta przejawia się przede wszystkim $\mathrm{w}$ dostosowaniu wy-

${ }^{1}$ Dz.U. z 2017 r., poz. 59.

2 Dz.U. z 2017 r., poz. 1656.

${ }^{3}$ Dz.U. z 2017 r., poz. 1743.

4 J. Bałachowicz, Indywidualizacja jako postulat i konieczność współczesnej edukacji początkowej [w:] Dziecko-uczeń a wczesna edukacja, red. I. Adamek, Z. Zbróg, Wydawnictwo LIBRON, Kraków, 2011, s. 11-30. 
korzystywanych $w$ codziennej pracy strategii edukacyjnych i wychowawczych, do potrzeb i możliwości ucznia. Możliwość wyboru sposobów osiągania celów, dostosowywanie tempa zajęć, metod i form zdobywania wiedzy i umiejętności do zróżnicowanych możliwości i preferencji ucznia daje nauczanie indywidualne.

Nauczanie indywidualne jest formą kształcenia specjalnego, wymagająca stosowania specjalnej organizacji nauki i metod pracy. Jego celem jest zapewnienie dzieciom $\mathrm{z}$ zaburzeniami $\mathrm{w}$ rozwoju możliwość realizacji obowiązku szkolnego. Mateusz Pilch ${ }^{5}$ zaznacza, że nie można wymagać od ucznia realizującego obowiązek szkolny wysiłku, jakim jest uczęszczanie do szkoły, jeżeli jego niepełnosprawność lub schorzenie stanowi rzeczywistą przeszkodę w tym działaniu, a jej przezwyciężenie łączyłoby się ze znacznym obciążeniem. Zgodnie z Ustawą o systemie oświaty z 7 września 1991 r. ${ }^{6}$ "indywidualnym obowiązkowym rocznym przygotowaniem przedszkolnym lub indywidualnym nauczaniem obejmuje się dzieci i młodzież, których stan zdrowia uniemożliwia lub znacznie utrudnia uczęszczanie do przedszkola lub szkoły". W nowej Ustawie z 14 grudnia 2016r. - Prawo oświatowe ${ }^{7}$ obowiązującej od dnia 1 września 2017 r., rozszerzono rodzaje placówek, w których dzieci i młodzież mogą zostać objęte nauczaniem indywidualnym o inne formy wychowania przedszkolnego, a także oddziały przedszkolne w szkole podstawowej.

Aby dziecko mogło zostać objęte nauczaniem indywidualnym konieczne jest uzyskanie: orzeczenia o potrzebie indywidualnego rocznego przygotowania przedszkolnego dzieci uczęszczających do przedszkola lub innej formy wychowania przedszkolnego lub orzeczenia o potrzebie indywidualnego nauczania dzieci i młodzieży, których stan zdrowia uniemożliwia lub znacznie utrudnia uczęsz-

${ }^{5}$ M. Pilch, Ustawa o systemie oświaty. Komentarz, Wydawnictwo Wolters Kluwer, Warszawa 2006.

${ }^{6}$ Obwieszczenie Marszatka Sejmu Rzeczypospolitej Polskiej z dnia 31 października 2016 r. w sprawie ogłoszenia jednolitego tekstu ustawy o systemie oświaty, Dz.U. 2016 poz. 1943 , art. 71 b., ust. 1a.

7 Dz.U. z 2017 r., poz. 59, 949, art. 127, ust. 2. 
czanie do szkoły - dla uczniów. Orzeczenia wydane są przez publiczną poradnię psychologiczno-pedagogiczną bądź publiczną poradnię specjalistyczną. Zgodnie $\mathrm{z}$ rozporządzeniem Ministra Edukacji Narodowej z dnia 18 września 2008 r. w sprawie orzeczeń i opinii wydawanych przez zespoły orzekające działające $\mathrm{w}$ publicznych poradniach psychologiczno-pedagogicznych, orzeczenie może zostać wydane tylko na wniosek rodzica bądź prawnego opiekuna dziecka. Do wniosku należy dołączyć zaświadczenie o stanie zdrowia dziecka, w którym lekarz określa:

- okres, nie krótszy jednak niż 30 dni, w którym stan zdrowia dziecka uniemożliwia lub znacznie utrudnia uczęszczanie do przedszkola lub szkoły;

- rozpoznanie choroby lub innej przyczyny powodującej, że stan zdrowia dziecka uniemożliwia lub znacznie utrudnia uczęszczanie do przedszkola lub szkoły;

- zakres, w jakim dziecko, któremu stan zdrowia znacznie utrudnia uczęszczanie do przedszkola, może brać udział w zajęciach, w których realizowana jest podstawa programowa wychowania przedszkolnego, organizowanych z grupą wychowawczą lub indywidualnie $\mathrm{w}$ odrębnym pomieszczeniu w przedszkolu;

- zakres, w jakim uczeń, któremu stan zdrowia znacznie utrudnia uczęszczanie do szkoły, może brać udział w obowiązkowych zajęciach edukacyjnych, organizowanych z oddziałem $\mathrm{w}$ szkole lub indywidualnie $\mathrm{w}$ odrębnym pomieszczeniu w szkole?.

Obecnie w nowym rozporządzeniu Ministra Edukacji Narodowej z 7 września 2017 r. w sprawie orzeczeń i opinii wydawanych przez zespoły orzekające działające $w$ publicznych poradniach psychologiczno-pedagogicznych ${ }^{10}$, zmieniono nazewnictwo na: orzeczenie o potrzebie indywidualnego obowiązkowego rocznego przygotowania przedszkolnego i orzeczenie o potrzebie indywi-

\footnotetext{
8 Dz.U. z 2008 r., nr 173 poz. 1072.

${ }_{9}^{9}$ Dz.U. z 2008 r., nr 173 poz. 1072.

${ }^{10}$ Dz.U. z 2017 r., poz. 1743.
} 
dualnego nauczania. Dołączone przez wnioskodawcę zaświadczenie o stanie zdrowia dziecka lub ucznia może wydać lekarz specjalista lub lekarz podstawowej opieki zdrowotnej, na podstawie dokumentacji medycznej leczenia specjalistycznego. W zaświadczeniu lekarz określa:

- przewidywany okres, nie krótszy jednak niż 30 dni, w którym stan zdrowia dziecka lub ucznia uniemożliwia lub znacznie utrudnia uczęszczanie do przedszkola lub szkoły;

- rozpoznanie choroby lub innego problemu zdrowotnego wraz $\mathrm{z}$ oznaczeniem alfanumerycznym, zgodnym $\mathrm{z}$ aktualnie obowiązującą Międzynarodową Statystyczną Klasyfikacją Chorób i Problemów Zdrowotnych (ICD);

- wynikające $\mathrm{z}$ tej choroby lub innego problemu zdrowotnego ograniczenia $\mathrm{w}$ funkcjonowaniu dziecka lub ucznia, które uniemożliwiają lub znacznie utrudniają uczęszczanie do przedszkola lub szkoły ${ }^{11}$.

Orzeczenie o potrzebie indywidualnego rocznego obowiązkowego przygotowania przedszkolnego oraz indywidualnego nauczania wydawane jest na okres nie dłuższy niż jeden rok szkolny. W orzeczeniach tych zespół określa:

- ograniczenia w funkcjonowaniu dziecka i ucznia wynikające z przebiegu choroby lub procesu terapeutycznego;

- okres, w jakim zachodzi potrzeba indywidualnego rocznego obowiązkowego przygotowania przedszkolnego oraz indywidualnego nauczania;

- zalecane warunki i formy wsparcia umożliwiające realizację indywidualnych potrzeb rozwojowych i edukacyjnych oraz możliwości psychofizycznych dziecka i ucznia, w tym warunki rozwijania jego potencjalnych możliwości i mocnych stron;

- zalecane działania sprzyjające integracji dziecka ze środowiskiem przedszkolnym szkolnym i ucznia ze środowiskiem szkolnym oraz ułatwiające powrót dziecka do przedszkola i ucznia do szkoły;

11 Dz.U. z 2017 r., poz. 1743, § 6. 
- zalecane, w zależności od potrzeb, cele rozwojowe i terapeutyczne do realizacji podczas zajęć indywidualnego rocznego obowiązkowego przygotowania przedszkolnego oraz indywidualnego nauczania oraz $\mathrm{w}$ ramach pomocy psychologiczno-pedagogicznej udzielanej (dziecku i) uczniowi i, w zależności od potrzeb, jego rodzicom przez przedszkole, szkołę oraz poradnię, wraz ze wskazaniem zalecanych form pomocy psychologiczno-pedagogicznej;

- w przypadku ucznia szkoły prowadzącej kształcenie zawodowe - także możliwość dalszego kształcenia w zawodzie, w tym warunki realizacji praktycznej nauki zawodu ${ }^{12}$.

Sposób i tryb organizowania indywidualnego nauczania dzieci i młodzieży do września 2017 r. określało rozporządzenie Ministra Edukacji Narodowej z 28 sierpnia 2014 r. w sprawie indywidualnego obowiązkowego rocznego przygotowania przedszkolnego dzieci i indywidualnego nauczania dzieci i młodzieży ${ }^{13}$. Nauczanie według przytoczonego dokumentu organizowane było na czas określony, w sposób zapewniający wykonanie zaleceń określonych w orzeczeniu. Zajęcia prowadzone były przez jednego lub kilku nauczycieli będących w indywidualnym i bezpośrednim kontakcie z uczniem. Odbywały się one w miejscu pobytu dziecka, zazwyczaj w domu rodzinnym. Mogły być również organizowane odpowiednio w przedszkolu, w innej formie wychowania przedszkolnego lub w szkole, jeżeli w orzeczeniu wskazano taką możliwość, a także w placówce, jeśli dysponowała oddzielnym pomieszczeniem, w którym mogły odbywać się zajęcia.

Dzieci i uczniowie, którym przyznano indywidualne roczne obowiązkowe przygotowanie przedszkolne lub nauczanie indywidualne przed 7 września 2017 r., kiedy w życie weszło rozporządzenie w sprawie orzeczeń i opinii wydawanych przez zespoły orzekające działające przy publicznych poradniach psychologiczno-pedagogicznych ${ }^{14}$, mogą nadal korzystać $\mathrm{z}$ takiej formy realizacji zajęć.

\footnotetext{
12 Dz.U. z 2017 r., poz. 1743, § 14, 15.

13 Dz.U. z 2014 r., poz. 1157.

14 Dz.U. z 2017 r., poz. 1743.
} 
Po tym terminie, orzeczenia wydawane są na podstawie nowego rozporządzenia Ministra Edukacji Narodowej z 9 sierpnia 2017 r. w sprawie indywidualnego obowiązkowego rocznego przygotowania przedszkolnego dzieci i indywidualnego nauczania dzieci i młodzieży ${ }^{15}$. Na mocy podanego aktu zajęcia indywidualnego przygotowania przedszkolnego oraz zajęcia indywidualnego nauczania prowadzi się w miejscu pobytu dziecka lub ucznia, w szczególności w domu rodzinnym oraz w placówkach: młodzieżowych ośrodkach wychowawczych, młodzieżowych ośrodkach socjoterapii, specjalnych ośrodkach szkolno-wychowawczych, specjalnych ośrodkach wychowawczych dla dzieci i młodzieży wymagających stosowania specjalnej organizacji nauki, metod pracy i wychowania, a także ośrodkach rewalidacyjno-wychowawczych umożliwiających dzieciom i młodzieży z głęboką niepełnosprawnością intelektualną, a także dzieciom i młodzieży z niepełnosprawnościami sprzężonymi, z których jedną z niepełnosprawności jest niepełnosprawność intelektualna, realizację odpowiednio, obowiązku szkolnego i obowiązku nauki ${ }^{16}$. Zajęcia mogą odbywać się również u rodziny zastępczej, w rodzinnym domu dziecka, w placówce opiekuńczo-wychowawczej lub w regionalnej placówce opiekuńczo-terapeutycznej, o których mowa w ustawie z dnia 9 czerwca 2011 r. o wspieraniu rodziny i systemie pieczy zastępczej ${ }^{17}$.

Obecne ustawodawstwo nie daje możliwości realizacji zajęć indywidualnego przygotowania przedszkolnego ani zajęć indywidualnego nauczania na terenie przedszkola lub szkoły. Obowiązkowe zajęcia edukacyjne realizowane podczas nauczania indywidulanego, wynikają z ramowego planu nauczania danego typu i rodzaju szkoły oraz dostosowane są do potrzeb rozwojowych, edukacyjnych i możliwości psychofizycznych ucznia, określonych w orzeczeniu o potrzebie indywidualnego obowiązkowego rocznego przygotowania przedszkolnego lub nauczania ${ }^{18}$.

\footnotetext{
15 Dz.U. z 2017 r., poz. 1616.

16 Ustawa z dnia 14 grudnia 2016 r. - Prawo oświatowe, art. 2, pkt 7.

17 Dz.U. z 2017 r., poz. 697 i 1292.

18 Dz.U. z 2017 r., poz. 1616.
} 


\section{Kontrowersje wokół nauczania indywidualnego}

Szkoła nie powinna służyć realizacji celów anonimowego społeczeństwa, ale powinna spełniać cele, pragnienia i aspiracje określonych uczestników edukacji. Powinna być instytucją stwarzającą szanse do samorealizacji, nieskrępowanego rozwoju osobowości, a także umożliwiającą osiąganie indywidualnych celów życiowych. $\mathrm{W}$ tak ujmowanej szkole, podkreśla Tadeusz Lewowicki ${ }^{19}$, przestaje obowiązywać jednolite formułowanie celów i zadań, a zakres swobody $\mathrm{w}$ kreowaniu modelu edukacji oraz własnego udziału jednostki w oświacie, wyznaczają normy ogólnospołeczne i zasada: niedziałania na szkodę innych.

Możliwość najlepszego dostosowania sposobów nauki i aktywizacji ucznia do jego sprawności i predyspozycji daje nauczanie indywidualne prowadzone $\mathrm{w}$ domu bądź $\mathrm{w}$ szkole. Uczeń objęty takim rodzajem edukacji, zaznacza K. Rzedzicka ${ }^{20}$, jest $w$ pozornie komfortowej sytuacji, gdyż najczęściej uczy się w swoim własnym otoczeniu domowym, ma własnego nauczyciela, który jest zaangażowany tylko w pracę $\mathrm{z}$ jednym, konkretnym uczniem, a jego uwaga i czas nie zostaje rozproszony na więcej osób, jak w przypadku klasy szkolnej. Jednak największym mankamentem prowadzenia nauczania w takich warunkach jest to, że przyczynia się do społecznej izolacji uczniów, którzy są nią objęci. Pozbawia ich także możliwości nawiązywania typowych dla wieku szkolnego relacji społecznych z osobami spoza rodziny, przede wszystkim z rówieśnikami.

Negatywne konsekwencje, jakie mogą wystąpić u dzieci objętych nauczaniem indywidualnym, B. Jachimczak ${ }^{21}$ zestawiła, uwzględ-

19 T. Lewowicki, Przemiany oświaty. Szkice o ideach i praktyce edukacyjnej, Wydawnictwo Akademickie Żak, Warszawa 1997.

${ }^{20}$ K. Rzedzicka, Kontrowersje wokót przejścia od nauczania indywidualnego do nauczania w zespole klasowym uczniów z mózgowym porażeniem dziecięcym, [w:] Nowatorskie $i$ alternatywne metody $w$ teorii i praktyce pedagogiki specjalnej, red. W. Dykcik, B. Szychowiak, Wydawnictwo Naukowe UAM, Poznań, 2001, s. 117-123.

21 B. Jachimczak, Dydaktyczne i pozadydaktyczne uwarunkowania efektów nauczania indywidualnego dzieci przewlekle chorych, Oficyna Wydawnicza „Impuls”, Kraków 2011, s. 10. 
- stały kontakt

- ciągła opieka

- brak pomocy specjalistów

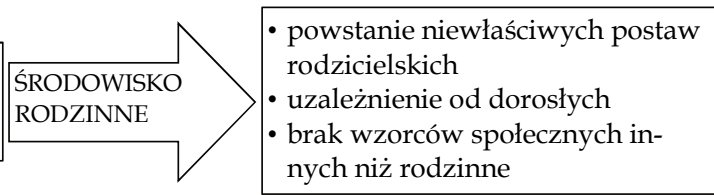

- mała liczba zajęć dydaktycznych

- nauczyciel bez specjalistycznego przygotowania

- kłopoty z organizacją procesu dydaktycznego

- brak włączania dziecka w "życie” społeczne klasy

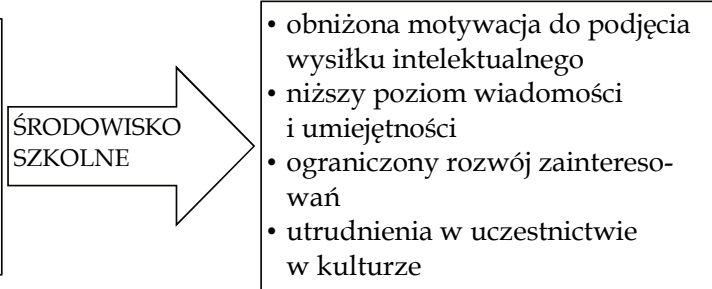

- ograniczenie kontaktów społecznych

- wykluczenie z grupy formalnej

- niezaspokojenie potrzeby zabawy

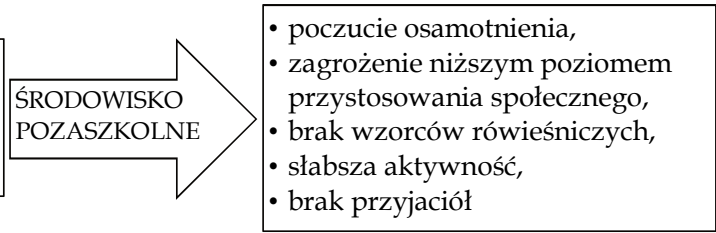

KONSEKWENCJE

- osamotnienie

- zaburzenia w zachowaniu: brak współdziałania, wykorzystywanie osób trzecich dla własnych korzyści,

- niższy poziom przystosowania społecznego

- uzależnienie od otoczenia: brak wiary we własne siły, brak samodzielności, niższy poziom niezależnego funkcjonowania

- gorsze wykształcenie: mała aktywność, brak samorealizacji

Schemat 1. Możliwe dla dziecka konsekwencje nauczania indywidualnego

Źródło: opracowanie własne, na podst. B. Jachimczak ${ }^{22}$

niając funkcjonowanie dziecka w najbliższych środowiskach: rodzinnym, szkolnym i pozaszkolnym (schemat 1).

Wskazane w schemacie 1 . konsekwencje wynikające $\mathrm{z}$ nauczania indywidualnego wpływają na dziecko nie tylko w zakresie funkcjonowania w szkole. Długotrwałe, przedłużane kolejnymi orzecze-

22 B. Jachimczak, op. cit., s. 10. 
niami nauczanie indywidualne może negatywnie oddziaływać na całe późniejsze życie, zarówno $\mathrm{w}$ aspekcie osobowościowym, jak i zawodowym. Ograniczenie kontaktów społecznych oraz trudności w ich nawiązywaniu mogą powodować nieprawidłowy rozwój społeczny i brak prawidłowych relacji interpersonalnych. Natomiast zmniejszenie wymogów edukacyjnych podczas nauczania indywidualnego wobec ucznia prowadzi do obniżenia poziomu wykształcenia i zdobywanych umiejętności. Zubożałe pod względem metodycznym zajęcia ograniczają możliwość wszechstronnego rozwoju psychoruchowego. Janina Wyczesany ${ }^{23}$ podkreśla, że nauczanie indywidualne jest jedną $\mathrm{z}$ trudniejszych form kształcenia zarówno dzieci, jak i młodzieży. Pozbawione jest ono wielu wartościowych cech, które posiada nauczanie i wychowanie w placówkach szkolnych: ogólnodostępnych, integracyjnych czy też specjalnych. Należy tu wyróżnić przede wszystkim kontakty z rówieśnikami oraz innymi nauczycielami, które niewątpliwie wzbogacają wiedzę i doświadczenia uczniów.

Odnosząc nauczanie indywidulane do pracy z dziećmi z różnego rodzaju niepełnosprawnością, J. Wyczesany ${ }^{24}$ wyodrębniła trzy modele organizacji edukacji indywidualnej, a także wynikające $\mathrm{z}$ niej niejednorodne konsekwencje dla rozwoju dziecka (schemat 2).

Rozporządzenie MEN z 28 sierpnia 2014 r. w sprawie indywidualnego obowiązkowego rocznego przygotowania przedszkolnego dzieci i indywidualnego nauczania dzieci i młodzieży ${ }^{25}$ dawało możliwość prowadzenia nauczania indywidualnego $\mathrm{w}$ modelu separacyjnym, mieszanym, bądź integracyjnym. Warunkiem organizacji edukacji według konkretnego modelu, podkreślał Departament

${ }^{23} \mathrm{~J}$. Wyczesany, Pedagogika upośledzonych umysłowo: wybrane zagadnienia, Oficyna Wydawnicza Impuls, Kraków 2005.

$24 \mathrm{~J}$. Wyczesany, Oligofrenopedagogika: wybrane zagadnienia pedagogiki upośledzonych umystowo, Oficyna Wydawnicza „Impuls”, Kraków, 1998; J. Wyczesany, Problemy edukacji dzieci i młodzieży niepetnosprawnej w systemie nauczania indywidualnego, [w:] Nowatorskie $i$ alternatywne metody w teorii i praktyce pedagogik specjalnej, red. W. Dykcik, B. Szychowiak, Wydawnictwo Naukowe UAM, Poznań 2001.

25 Dz.U. z 2014 r., poz. 1157. 


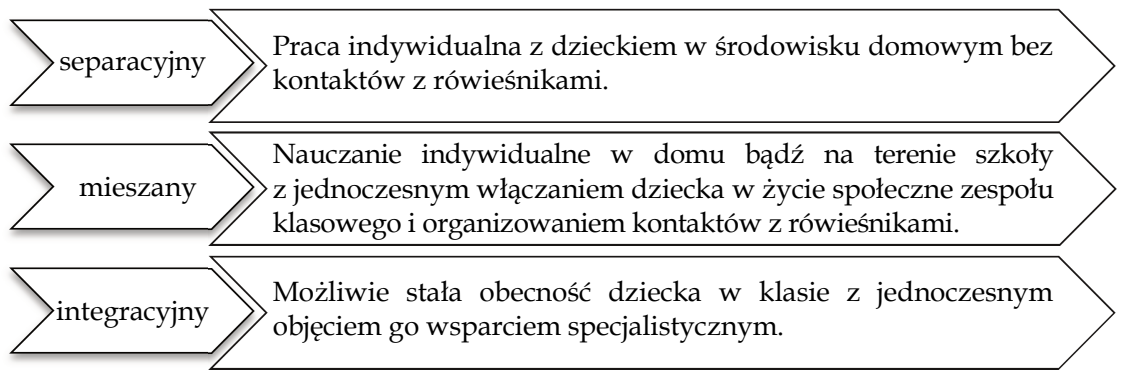

Schemat 2. Modele edukacji indywidualnej

Źródło: oprac. własne na podst. J. Wyczesany ${ }^{26}$, B. Jachimczak ${ }^{27}$

Informacji i Promocji Ministerstwa Edukacji Narodowej28, było wskazanie takiej możliwości $\mathrm{w}$ orzeczeniu wydanym przez poradnię psychologiczno-pedagogiczną, na podstawie zaświadczenia lekarza kierującego. Po wprowadzeniu nowego rozporządzenia Ministra Edukacji Narodowej z 9 sierpnia 2017 r. w sprawie indywidualnego obowiązkowego rocznego przygotowania przedszkolnego dzieci i indywidualnego nauczania dzieci i młodzieży ${ }^{29}$, dzieci i uczniowie nie mają możliwości nauczania indywidualnego w szkole. Dlatego możliwość realizacji mają tylko dwa z wymienionych modeli: separacyjny i mieszany, z uwzględnieniem nauczania tylko w domu. Dla modelu integracyjnego ustawodawca zakłada inne rozwiązania $^{30}$, które nie dotyczą dziecka $\mathrm{z}$ orzeczeniem o indywidualnym

26 J. Wyczesany, Oligofrenopedagogika: wybrane zagadnienia...; J. Wyczesany, Problemy edukacji dzieci i młodzieży niepetnosprawnej $w$ systemie nauczania indywidualnego, [w:] Nowatorskie $i$ alternatywne metody w teorii i praktyce pedagogik specjalnej, red. W. Dykcik, B. Szychowiak, Wydawnictwo Naukowe UAM, Poznań, 2001

27 B. Jachimczak, op. cit.

28 https://men.gov.pl/ministerstwo/informacje/czy-uczniowie-objeci-indywidu alnym-nauczaniem-moga-brac-udzial-w-zajeciach-dla-klas-odpowiedz-na-watpliwos ci.html [dostęp: 19.03.2018].

${ }^{29}$ Dz.U. z 2017 r., poz. 1616.

30 Por. Rozporządzenie Ministra Edukacji Narodowej z dnia 9 sierpnia 2017 r. w sprawie zasad organizacji i udzielania pomocy psychologiczno-pedagogicznej w publicznych przedszkolach, szkołach i placówkach, Dz.U. z 2017 r. poz. 1591. 
obowiązkowym rocznym przygotowaniu przedszkolnym oraz ucznia $\mathrm{z}$ indywidualnym nauczaniem, i nie są tematem niniejszego rozważania.

Najkorzystniejszy dla dziecka i niosący ze sobą najmniej negatywnych konsekwencji jest model integracyjny, kiedy dziecko może przebywać z grupą szkolną i odbywać zajęcia indywidualne. $Z$ kolei najmniej korzystnym ze względu na rozwój emocjonalnospołeczny oraz poznawczy dziecka jest model separacyjny, kiedy uczeń pozostając w domu, zostaje "odcięty” od kontaktów z grupą rówieśniczą i traci możliwość poszerzania swojej wiedzy oraz zainteresowań. Model mieszany sprawdza się w sytuacji, gdy uczeń ze względu na stan zdrowa nie może stale uczestniczyć w zajęciach klasowych. Wobec licznych negatywnych konsekwencji nauczania indywidualnego, należy zastanowić się nad częstotliwością i kierunkowością wskazań orzekania o jego potrzebie

\section{Założenia badań własnych}

Głównym celem przeprowadzonych badań było określenie tendencji $\mathrm{w}$ orzecznictwie nauczania indywidualnego, uwzględniając: liczba wydawanych orzeczeń w odniesieniu do wszystkich uczniów $\mathrm{z}$ danego powiatu, liczba dzieci objętych nauczaniem indywidualnym na poszczególnych etapach edukacji oraz najczęstsze przyczyny wydawania orzeczeń. Uzyskane dane zostały zebrane metodą sondażu diagnostycznego, techniką analizy dokumentów oraz uzupełnione wywiadami z dyrektorami tych placówek.

Badania przeprowadzono $\mathrm{w}$ pięciu wybranych publicznych poradniach psychologiczno-pedagogicznych, $w$ należących do województwa małopolskiego trzech powiatach:

- wadowickim: Poradnia Psychologiczno-Pedagogiczna w Wadowicach i w Andrychowie,

- myślenickim: Poradnia Psychologiczno-Pedagogiczna w Myślenicach i w Dobczycach,

- krakowskim, miasto Kraków: Poradnia Psychologiczno-Pedagogiczna nr 2 w Krakowie. 
Dobór był celowy ze względu na ilość podlegających poradniom uczniów w danym rejonie. W powiatach wadowickim i myślenickim, dane zostały zebrane we wszystkich poradniach publicznych, natomiast w przypadku miasta Kraków na prawach powiatu, wybrana została tylko jedna z czterech poradni, posiadających prawo do wydawania orzeczeń o nauczaniu indywidualnym. Udostępnione przez poradnie dane za rok szkolny 2015/2016, celem zobrazowania liczby wydawanych orzeczeń o nauczaniu indywidualnym w stosunku do liczby uczniów na danym etapie edukacyjnym, zestawiono z danymi Urzędu Statystycznego w Krakowie dotyczącymi szkolnictwa za rok 2014/201531.

\section{Tendencje w częstotliwości i wskazaniach orzekania o potrzebie nauczania indywidualnego - wyniki badań własnych}

Pierwszym z aspektów nauczania indywidualnego, ktory został przeanalizowany, jest częstotliwość przyznawania tego typu edukacji na tle całościowej populacji uczniów uczęszczających do placówek edukacyjnych w badanych powiatach (tabela 1).

Zestawiając dane ilościowe uzyskane $\mathrm{w}$ badanych poradniach psychologiczno-pedagogicznych z danymi Urzędu Statystycznego w Krakowie, można stwierdzić, że w powiatach: wadowickim $(0,94 \%)$ i myślenickim $(0,81 \%)$ blisko $1 \%$ dzieci spośród wszystkich uczniów objętych jest nauczaniem indywidualnym. W mieście Kraków badany odsetek dzieci wynosi 0,45\%, jednak należy zwrócić uwage, że analizowano tylko dane z jednej poradni psychologicznopedagogicznej spośród czterech posiadujących uprawnienia do wydawania orzeczeń.

Odnosząc się do liczby orzeczeń wydawanych w poszczególnych poradniach i porównując je z etapem edukacji, można zauwa-

${ }^{31} \mathrm{http}$ // / krakow.stat.gov.pl/statystyczne-vademecum-samorzadowca [dostęp: 19.03.2018]. 


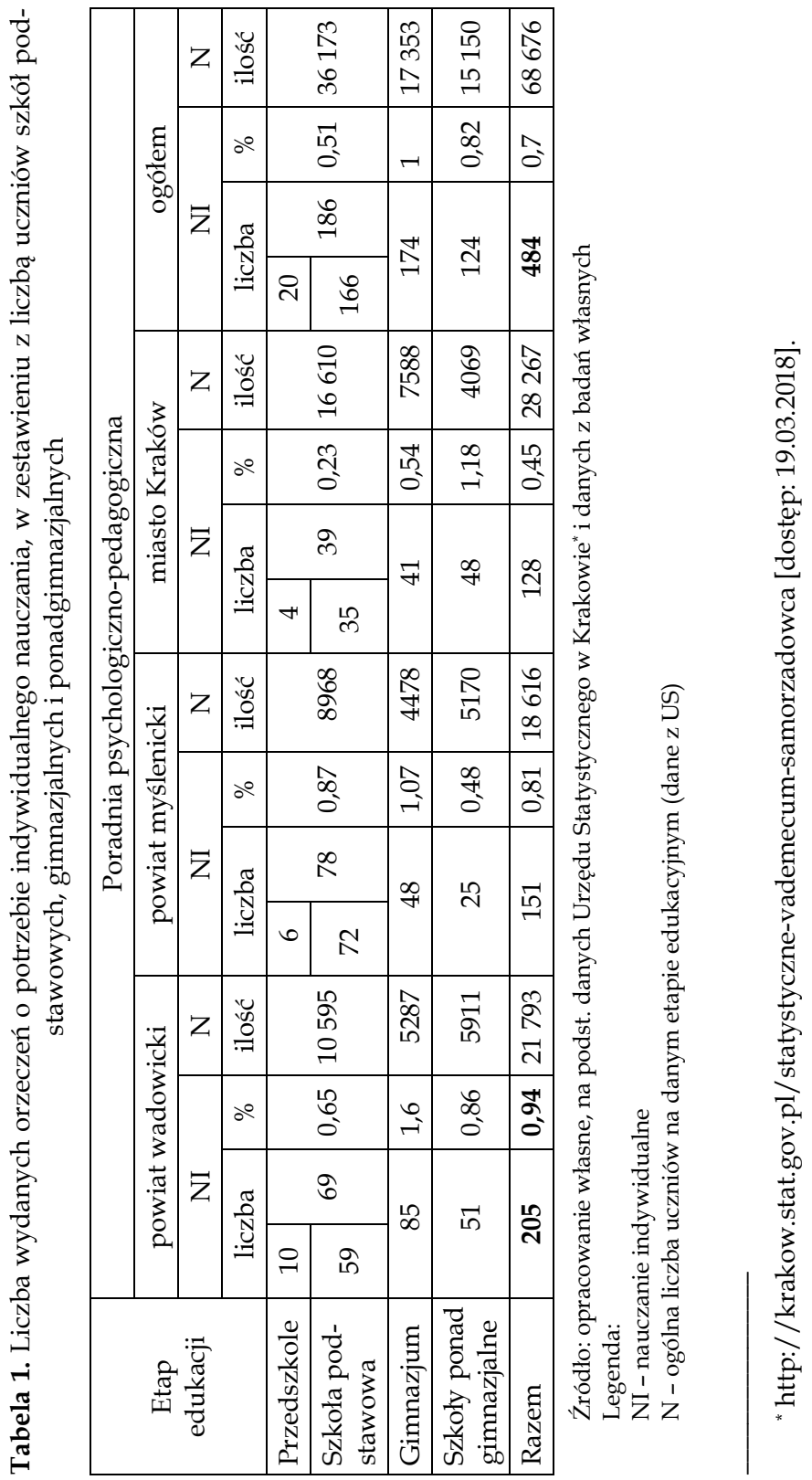


Tendencje w orzekaniu o potrzebie nauczania indywidualnego

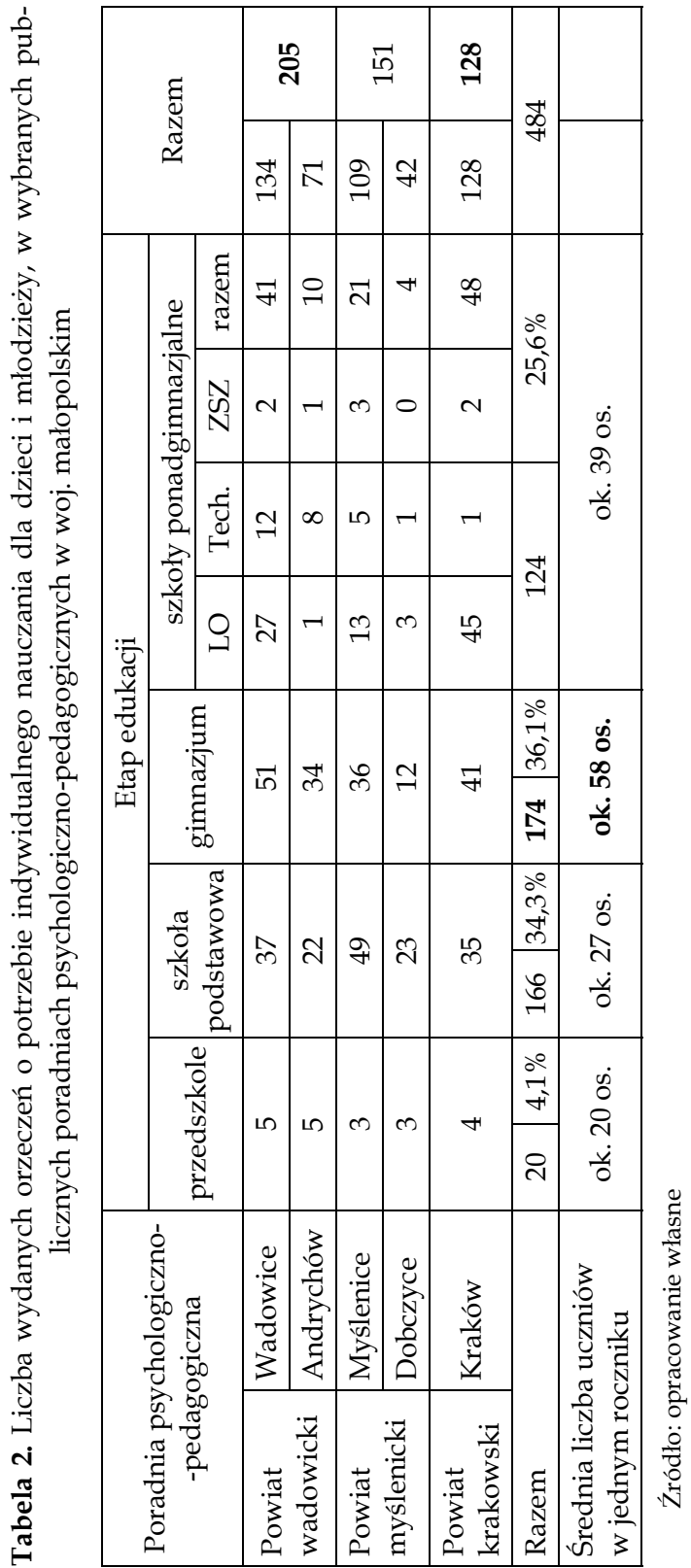


żyć, że zarówno w powiecie wadowickim $(1,6 \%)$, jak i myślenickim $(1,07 \%)$ nauczanie indywidualne najczęściej przyznawane jest uczniom szkół gimnazjalnych. Z kolei w mieście Kraków takie orzeczenie otrzymują najczęściej uczniowie szkół ponadgimnazjalnych (1,18\%).

W kolejnej części badań skoncentrowano się na określeniu liczby orzeczeń o potrzebie nauczania indywidualnego z uwzględnieniem etapu edukacji (tabela 2).

Analizując dane uwzględniające etap edukacji, zaobserwowano, że najwięcej orzeczeń o potrzebie nauczania indywidualnego otrzymywali uczniowie gimnazjum $(36,1 \%)$. Biorąc pod uwagę trzy lata nauczania na tym poziomie edukacji, można przypuszczać, że średnio na jeden rocznik przypadało 58 uczniów objętych nauczaniem indywidualnym. Również uczniowie szkół podstawowych stanowili dość duży odsetek $(34,3 \%)$ objętych tą forma edukacji. Jednak uwzględniając sześcioletni system nauki, na jeden rocznik przypadało średnio 27 uczniów. Z kolei ilość młodzieży w szkołach ponadgimnazjalnych $(25,6 \%)$ była nieco mniejsza, porównując z opisanymi wcześniej etapami edukacji, ale uwzględniając czas trwania tego etapu edukacji (3-4 lata), w ciągu jednego rocznika było to średnio 39 osób. Najmniej dzieci objętych było rocznym indywidualnym obowiązkowym przygotowaniem przedszkolnym i stanowiło $4,1 \%$, czyli w ciągu roku obejmowało 20 dzieci.

Wobec takiej liczby wydawanych orzeczeń na poszczególnych etapach edukacyjnych, zastanawiającym wydają się przyczyny i wskazania, zgodnie z którymi lekarz kieruje dziecko na nauczanie indywidualne (tabela 3).

Analizując dane zawarte $\mathrm{w}$ tabeli 3., można zauważyć, że prawie co drugie orzeczenie o potrzebie nauczania indywidualnego wydawane jest uczniom, u których lekarz stwierdził różnego rodzaju zaburzenia psychiczne $(48,7 \%)$. Z kolei niemal co czwarte wskazanie dotyczy choroby przewlekłej, uniemożliwiającej lub znacznie utrudniającej uczęszczanie do przedszkola lub szkoły (24\%). Tylko co dziesiąte orzeczenie związane jest $\mathrm{z}$ operacją bądź wypadkiem $(9,7 \%)$, a co dwudzieste $\mathrm{z}$ chorobą nowotworową $(4,9 \%)$ lub ciążą $(3,1 \%)$. 


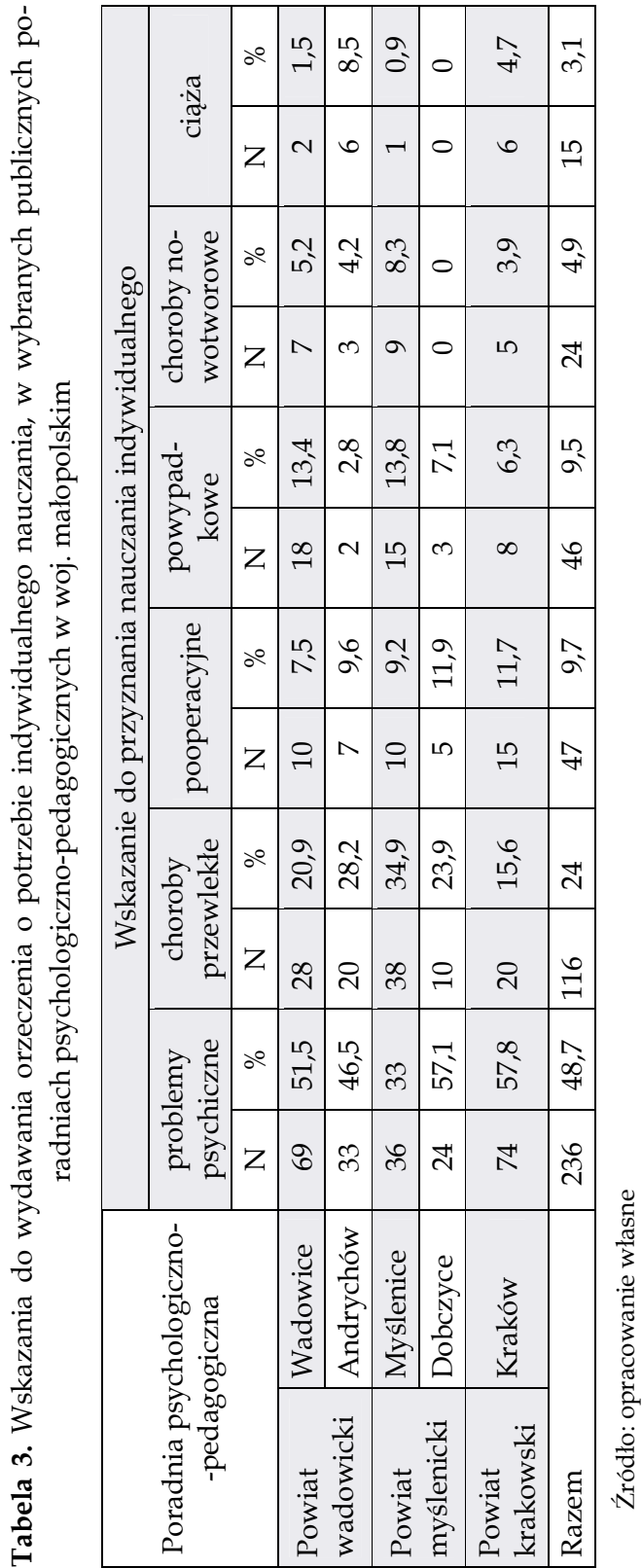




\section{Podsumowanie}

Nauczanie indywidualne jest formą kształcenia specjalnego, która pozwala realizować obowiązek szkolny dzieciom, których stan zdrowia uniemożliwia lub znacznie utrudnia uczęszczanie do przedszkola lub szkoły. Ze względu na swoją specyfikę, daje możliwość całkowitego dostosowania edukacji do możliwości psychofizycznych ucznia i jego preferencji w nabywaniu wiedzy i umiejętności. Zazwyczaj nauczanie indywidualne odbywa się $\mathrm{w}$ domu dziecka, ograniczając $w$ znaczny sposób jego kontakty z rówieśnikami i zaburzając rozwój. $W$ uzasadnionych przypadkach jest to działanie pozytywne - możliwości elastycznego dostosowywania modelu nauczania indywidualnego do danego ucznia, jego aktualnego stanu zdrowia, kondycji psychicznej w konkretnym momencie jego życia daje szanse na lepsze funkcjonowanie. Niestety często jednak staje się "wygodnym" rozwiązaniem dla szkoły zmagającej się $\mathrm{z}$ "trudnym uczniem". Taka izolacja społeczna negatywnie wpływa na indywidualny i społeczny rozwój młodego człowieka, którego podstawowym warunkiem, podkreśla Władysław Dykcik32, jest umożliwienie uczestnictwa $\mathrm{w}$ życiu społecznym $\mathrm{w}$ różnych zakresach, sytuacjach i kontekstach.

Na podstawie analizy zgromadzonych danych $\mathrm{z}$ wybranych poradni psychologiczno-pedagogicznych $\mathrm{w}$ województwie małopolskim można stwierdzić, że orzeczenie o potrzebie nauczania indywidualnego otrzymuje blisko $1 \%$ spośród wszystkich uczniów, najczęściej na etapie szkoły gimnazjalnej. A najczęstszą przyczyną i wskazaniem są choroby psychiczne oraz schorzenia przewlekłe. $\mathrm{Z}$ takich wskazań można wnioskować, że przyznawane orzeczenia, zgodnie z aktualnie obowiązującym rozporządzeniem, wydawane będą na najdłuższy możliwy czas, czyli na rok szkolny.

32 W. Dykcik, Poszukiwanie nowatorskich i alternatywnych koncepcji indywidualnej rehabilitacji oraz społecznej integracji osób niepetnosprawnych - aktualnym wyzwaniem praktyki edukacyjnej [w:] Nowatorskie i alternatywne metody w teorii i praktyce pedagogik specjalnej, red. W. Dykcik, B. Szychowiak, Wydawnictwo Naukowe UAM, Poznań 2001. 
Zastanawiając się nad przyczyną połączenia konkretnego etapu edukacyjnego i rodzaju wskazań, można przypuszczać, że duża liczba wystawianych orzeczeń u gimnazjalistów może być spowodowana zbyt późną diagnozą, symptomami ujawniającymi się dopiero $\mathrm{w}$ okresie adolescencji albo też rodzajem deficytów, które utrudniają naukę dopiero na późniejszym etapie edukacji szkolnej.

$\mathrm{W}$ odniesieniu do zebranych danych empirycznych należy postawić pytanie o zasadność wystawiania tak dużej liczby orzeczeń o nauczaniu indywidualnym oraz jakość organizacji tej formy kształcenia. Nowe przepisy oraz zaproponowane w nich rozwiązania mają zmierzać do ograniczenia takiej formy edukacji do minimum. Czy się to uda?

Warto $\mathrm{w}$ tym miejscu podkreślić, że nauczanie indywidualne powinno być jednym z ostatecznych sposobów realizacji obowiązku szkolnego. Nadużywanie tej formy kształcenia jest niekorzystne z punktu widzenia rozwoju młodego człowieka. Dlatego warto zastanowić się, dlaczego tak dużo dzieci korzysta z tej formy kształcenia? Należy weryfikować przyznawane orzeczenia o potrzebie nauczania indywidualnego, aby nie stały się one formą wyeliminowania problemów i trudności wynikających z pracy z uczniem o specjalnych potrzebach edukacyjnych.

\section{Bibliografia}

Bałachowicz J., Indywidualizacja jako postulat $i$ konieczność wspótczesnej edukacji poczatkowej, [w:] Dziecko-uczeń a wczesna edukacja, red. I. Adamek, Z. Zbróg, Wydawnictwo LIBRON, Kraków 2011.

Dykcik W., Poszukiwanie nowatorskich $i$ alternatywnych koncepcji indywidualnej rehabilitacji oraz społecznej integracji osób niepetnosprawnych - aktualnym wyzwaniem praktyki edukacyjnej, [w:] Nowatorskie i alternatywne metody w teorii i praktyce pedagogik specjalne, red. W. Dykcik, B. Szychowiak, Wydawnictwo Naukowe UAM, Poznań 2001.

Jachimczak B., Dydaktyczne i pozadydaktyczne uwarunkowania efektów nauczania indywidualnego dzieci przewlekle chorych, Oficyna Wydawnicza „Impuls”, Kraków 2011

Lewowicki T., Przemiany oświaty. Szkice o ideach i praktyce edukacyjnej, Wydawnictwo Akademickie Żak, Warszawa 1997. 
Obwieszczenie Marszatka Sejmu Rzeczypospolitej Polskiej z dnia 31 października 2016 r. w sprawie ogłoszenia jednolitego tekstu ustawy o systemie oświaty, Dz. U. 2016 poz. 1943.

Pilch M., Ustawa o systemie oświaty. Komentarz. Wydawnictwo Wolters Kluwer, Warszawa 2006.

Rozporzadzenia Ministra Edukacji Narodowej z dnia 9 sierpnia 2017 r. w sprawie indywidualnego obowiazkowego rocznego przygotowania przedszkolnego dzieci i indywidualnego nauczania dzieci i młodzieży, Dz.U. z 2017 r., poz. 1616.

Rozporządzenie Ministra Edukacji Narodowej z dnia 18 września 2008 r. w sprawie orzeczeń $i$ opinii wydawanych przez zespoty orzekajace działajace $w$ publicznych poradniach psychologiczno-pedagogicznych, Dz.U. nr 173, poz. 1072.

Rozporzadzenie Ministra Edukacji Narodowej z dnia 28 sierpnia 2014 r. w sprawie indywidualnego obowiazkowego rocznego przygotowania przedszkolnego dzieci i indywidualnego nauczania dzieci i młodzieży, Dz.U. 2014 poz. 1157.

Rozporzadzenie Ministra Edukacji Narodowej z dnia 28 sierpnia 2017 r. zmieniajacego rozporzadzenie w sprawie indywidualnego obowiazkowego rocznego przygotowania przedszkolnego dzieci i indywidualnego nauczania dzieci i młodzieży, Dz.U. z 2017 r. poz. 1656.

Rozporzadzeniem Ministra Edukacji Narodowej z dnia 7 września 2017r. w sprawie orzeczeń $i$ opinii wydawanych przez zespoty orzekajace działające w publicznych poradniach psychologiczno-pedagogicznych, Dz.U. 2017 poz. 1743.

Rzedzicka K., Kontrowersje wokót przejścia od nauczania indywidualnego do nauczania w zespole klasowym uczniów z mózgowym porażeniem dziecięcym, [w:] Nowatorskie $i$ alternatywne metody w teorii i praktyce pedagogik specjalnej, red. W. Dykcik, B. Szychowiak, Wydawnictwo Naukowe UAM, Poznań 2001.

Ustawa z dnia 14 grudnia 2016 r. - Prawo oświatowe, Dz.U. z 2017 r., poz. 59 i 949.

Ustawa $z$ dnia 9 czerwca 2011 r. o wspieraniu rodziny $i$ systemie pieczy zastępczej, Dz.U. z 2017 r. poz. 697 i 1292.

Wyczesany J., Oligofrenopedagogika: wybrane zagadnienia pedagogiki upośledzonych umystowo, Oficyna Wydawnicza „Impuls”, Kraków 1998.

Wyczesany J., Pedagogika upośledzonych umystowo: wybrane zagadnienia, Oficyna Wydawnicza „Impuls”, Kraków 2005.

Wyczesany J., Problemy edukacji dzieci i młodzieży niepetnosprawnej w systemie nauczania indywidualnego, [w:] Nowatorskie i alternatywne metody w teorii i praktyce pedagogik specjalnej, red. W. Dykcik, B. Szychowiak,. Wydawnictwo Naukowe UAM, Poznań 2001.

http://krakow.stat.gov.pl/statystyczne-vademecum-samorzadowca/

https://men.gov.pl/ministerstwo/informacje/czy-uczniowie-objeci-indywidualnymnauczaniem-moga-brac-udzial-w-zajeciach-dla-klas-odpowiedz-na-watpliwos ci.html [dostęp: 19.03.2018]. 